\title{
Diksi dan bahasa figuratif pada komik Si Juki: Lika-Liku Anak Kos karya Faza Meonk sebagai alternatif bahan ajar di SMA
}

Wiwit Meilani a,1, Haryadi b,2,*

Program Studi Pendidikan Bahasa dan Sastra Indonesia FKIP, UAD

1Wiwitmeilani05@gmail.com ; ${ }^{2 H a r y a d i . u a d @ g m a i l . c o m ~}$

\section{ARTICLE INFO}

\section{Article history}

Received

Revised

Accepted

Keywords

Diksi dan Bahasa Figuratif

Komik

Cerpen

ABSTRACT

Penelitian ini dilatarbelakangi oleh unsur-unsur pembangun gaya bahasa mengenai diksi dan bahasa figuratif khususnya pada komik Si Juki yang kemudian dikaitkan dengan teks cerpen. Tujuan penelitian ini untuk: (1) Mendeskripsikan diksi yang terdapat dalam komik Si Juki: Lika-Liku Anak Kos karya Faza Meonk, (2) mendeskripsikan bahasa figuratif yang terdapat dalam komik Si Juki: Lika-Liku Anak Kos karya Faza Meonk, dan (3) mendeskripsikan komik Si Juki: LikaLiku Anak Kos karya Faza Meonk sebagai alternatif bahan ajar sastra di SMA. Metode analisis data yaitu dengan metode deskriptif kualitatif. Metode ini berfungsi untuk menyelesaikan masalah dengan cara mengumpulkan, mengidentifikasi, mengklasifikasi, mengkaji, menyusun,dan menyimpulkan berdasarkan hasil kajian. Hasil analisis menunjukkan bahwa diksi dan bahasa figuratif menjadi aspek gaya bahasa yang dipilih oleh pengarang guna memperindah kalimat. Pengarang lebih dominan menggunakan kata asing sebagai diksi yang tepat untuk mengekspresikan ide gagasan dalam cerita. Pengarang lebih menggunakan kata yang modern karena mengikuti perkembangan yang semakin maju. Selaras dengan hal tersebut dari tiga aspek kriteria bahan ajar yang disampaikan oleh Rahmanto dapat disimpulkan bahwa komik "Si Juki: Lika-Liku Anak Kos" karya Faza Meonk menjadi alternatif yang tepat untuk dijadikan sebagai bahan ajar sastra di SMA karena memenuhi semua kriteria tersebut.

This is an open-access article under the CC-BY-SA license.

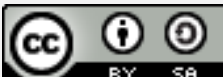

\section{Pendahuluan}

Di era sekarang ini karya sastra sudah bukan menjadi hal yang asing lagi untuk didengar. Hingga dari berbagai kalangan menyukai karya sastra. Sastra menurut Wellek \& Warren (2016) yaitu suatu kegiatan kreatif, sebuah karya seni yang menggunakan imajinasi serta pemilihan kata tertentu guna menciptakan efek makna tertentu. Karya sastra adalah karya seni yang dibuat oleh seseorang di mana karya tersebut memiliki tujuan estetika yang di sampaikan dengan imajinatif dan komunikatif melalui bahasa penulis sendiri. Jenis karya sastra dibedakan menjadi dua jenis, yaitu fiksi dan nonfiksi. Pada penulisan sebuah karya sastra pengarang sangat memikirkan dalam 
pemilihan kata atau diksi yang akan digunakan. Hal tersebut sudah menjadi hal wajib dilakukan agar penyampaian gagasan atau ide dapat tersampaikan dengan baik kepada pembaca.

Sejak tahun 2000-an akses internet semakin mudah dijangkau, perkembangan karya sastra di Indonesia sudah mulai berkembang cukup signifikan. Komik menjadi salah satu karya sastra yang sudah mulai berkembang di berbagai media digital. Komik dari komikus Indonesia yang sudah terkenal secara Internasional yaitu My Pre-Wedding karya Annisa Nisfi'hani, Tahilalats karya Nurfadli Mursyid dan Si Juki karya faza moenk. Saat ini untuk membaca komik sudah dapat diakses melalui situs web. Webcomic atau biasa dikenal sebagai komik online atau komik internet merupakan komik daring yang diterbitkan pada situs web. Sehingga para pembaca dapat menemukan atau membaca komik pada situs web komik tersebut secara daring. Selain itu dapat juga diakses melalui Line Webtoon. Oleh sebab itu, komik dipilih untuk dikaji sebagai bahan ajar di SMA agar siswa dapat mempelajari gaya bahasa diksi dan bahasa figuratif dari teks bacaan komik, tidak hanya dari buku novel atau cerpen saja. Selain itu penelitian ini dilatarbelakangi oleh unsur-unnsur pembangun gaya bahasa mengenai diksi dan bahasa figuratif khususnya pada komik Si Juki yang kemudian dikaitkan dengan teks cerpen.

Karya sastra komik merupakan karya yang berbentuk cerita pendek dengan gambar yang menarik, dan menceritakan kisah kehidupan salah satu tokoh yang diunggulkan. Menurut Darmawan (dalam Ahmad Fadhlin Batubara, 2013) komik adalah mengungkapkan ide/bercerita melalui gambar, dengan kata lain komik yaitu media bercerita atau berekspresi dengan bahasa gambar yang tersusun. Bahasa-bahasa yang digunakan pada komik sangat santai atau bahasa sehari-hari sehingga komik tersebut dapat mudah di mengerti dan dipahami oleh pembaca. Pada komik tersebut memiliki gaya bahasa yang menjadi ciri khas penulis. Pada komik Si Juki: Lika-Liku Anak Kos tersebut penulis lebih sering memanfaatkan kata asing untuk membantu mengekspresikan ide cerita. Terdapat beberapa bahasa figuratif seperti majas, peribahasa dan lain sebagainya. Selain itu, komik dengan tampilan berupa gambar membuat kejadian yang diceritakan dapat dilihat secara langsung oleh pembaca. Komik sebagai media karya atau bahan ajar yang bertujuan untuk mengekspresikan gagasan atau ide dengan gambar, dengan kombinasi teks atau informasi visual lainnya. Hal tersebut menjadi salah satu daya tarik pembaca.

Melihat perkembangan komik di berbagai media digital dan di Indonesia menjadi salah satu alasan diperlukannya studi atau penelitian mengenai komik. Penelitian ini mengkaji terkait gaya bahasa khususnya mengenai diksi dan bahasa figuratif yang terdapat dalam komik. Contoh bahasa figuratif yang terdapat dalam komik, yaitu kalimat "mbah curiga, jangan-jangan ini kerannya kesurupan" kalimat tersebut memiliki makna menyamakan suatu benda keran dengan manusia. Gaya bahasa merupakan salah satu cara untuk mengungkapkan suatu pikiran dan perasaan melalui bahasa secara khas yang memperlihatkan jiwa si penulis (pemakaian bahasa), (Keraf dalam Al-Ma'aruf, 2009: 9). Melalui berbagai jenis gaya bahasa pengarang dapat mengekspresikan ide dan pikiran ke dalam karya sastra sehingga pembaca ikut terbawa ke dalam isi cerita tersebut. Alasan memilih gaya bahasa sebagai objek karena penulis ingin memahami lebih dalam mengenai makna dari gaya bahasa yang terdapat pada komik "Si Juki: Lika-Liku Anak Kos" karya Faza Meonk. Tetapi, penelitian ini penulis memfokuskan hanya pada gaya kata (diksi) dan bahasa figuratif yang terkandung dalam komik.

Komik berjudul "Si Juki: Lika-Liku Anak Kos" ini adalah serial komik Indonesia yang ditulis oleh Faza Ibnu Ubaidillah Salman atau biasa dikenal dengan sapaan Faza Meonk. Komik ini awalnya diterbitkan sebagai webcomic pada tahun 2010. Penelitian komik Si Juki: Lika-Liku Anak Kos ini sangat menarik untuk dikaji karena pada komik tersebut memuat berbagai gaya bahasa. Komik termasuk media yang cocok untuk dibaca oleh siswa SMA. Selain dapat menarik minat belajar siswa karena terdapat gambar-gambar di dalamnya, bahasa yang digunakan pada buku 
komik "Si Juki Lika-Liku Anak Kos" ini relatif bahasa sehari-hari. Bahasa yang sering digunakan anak muda kekinian, santai, tidak berat, dan pesannya mudah dipahami oleh pembaca. Yang menjadi daya tarik dalam komik ini yaitu penggunaan gaya kata, dan bahasa figuratif yang digunakan cukup unik dan menggelitik para pembacanya. Selain itu, pada komik "Si Juki: Lika-Liku Anak Kos" tersebut gaya bahasa yang digunakan banyak melontarkan humor dan cenderung lisan karena terdapat pada balon dialog. Berikut contoh teks cerita pada komik "Si Juki Lika-Liku Anak Kos" yang membuat menarik untuk diteliti.

Pembelajaran bahasa atau sastra di sekolah dapat memanfaatkan komik sebagai alternatif bahan ajar di sekolah. Komik Si Juki Lika-Liku Anak Kos yang ditulis oleh Faza Meonk ini sesuai untuk diterapkan ke dalam pembelajaran sastra karena memenuhi tiga aspek bahan pengajaran sastra, yang meliputi (1) bahasa, (2) psikologis, (3) latar belakang budaya (Rahmanto, 1988: 27). Alternatif pembelajaran yang ditawarkan berdasarkan kurikulum 2013 yang berbasis teks adalah dengan mengaitkan pembelajaran sastra ini dengan Kompetensi Dasar. Hasil penelitian diksi dan bahasa figuratif dalam komik ini akan dikaitkan dengan pembelajaran bahasa Indonesia kelas XI SMA dengan kompetensi dasar (KD) 3.8 dan KD 4.8. KD 3.8, yaitu mengidentifikasi nilai nilai kehidupan yang terkandung dalam kumpulan cerita pendek yang dibaca, sedangkan KD 4.8, yaitu mendemonstrasikan salah satu nilai kehidupan yang dipelajari dalam cerita pendek. Pembelajaran sastra ini bisa dijadikan sebagai pembelajaran yang menarik dalam melatih kemampuan siswa menganalisis unsur-unsur pembangun yang terdapat pada teks cerpen tersebut, baik dari unsur intrinsik maupun unsur ekstrinsik.

Berdasarkan pembacaan peneliti, ditemukan beberapa tulisan yang berkaitan dengan penelitian ini. Pertama, skripsi berjdudul "Gaya Bahasa dalam Meme Indonesia: Kajian Stilistika Sastra" yang ditulis oleh Aprian Kurniawan, (2017) dari Universitas Diponegoro. Skripsi tersebut bertujuan untuk mendeskripsikan kedudukan meme dalam dunia sastra, dan memaparkan berbagai macam majas yang dipakai dalam meme. Persamaan skripsi tersebut dengan penelitian ini adalah sama-sama mengkaji gaya bahasa. Perbedaan skripsi tersebut dengan penelitian ini adalah skripsi tersebut menggunakan meme sebagai objek, sedangkan penelitian ini menggunakan komik untuk dijadikan objek penelitian serta sebagai alternatif bahan ajar di SMA.

Kedua, artikel berjudul "Diksi dan Gaya Bahasa Pada Cerpen Anak Ini Mengencingi Jakarta? Dan Relevansinya dengan Materi Ajar di SMA" yang ditulis oleh Alif Fatin Febriani, dkk. (2019) dari Universitas Sebelas Maret dalam BASASTRA Jurnal Bahasa, Sastra, dan Pengajarannya Vol. 7 No. 1, April 2019. Artikel tersebut bertujuan untuk menjelaskan pemakaian diksi, bentuk gaya bahasa; dan relevansi Antologi 'Cerpen Pilihan Kompas 2015 Anak Ini Mau Mengencingi Jakarta?' sebagai materi ajar pembelajaran Bahasa Indonesia di SMA kelas X Kurikulum 2013. Persamaan jurnal tersebut dengan penelitian ini adalah mengkaji penelitian yang ditujukan kepada siswa SMA, dan sama-sama mengkaji di bidang gaya bahasa. Perbedaan jurnal tersebut dengan penelitian ini adalah artikel dalam jurnal tersebut ditujukan kepada kelas X SMA, dan bidang yang dikaji yaitu diksi serta gaya bahasanya, dan objek yang digunakan yaitu menggunakan cerpen pilihan kompas 2015. Sedangkan penelitian ini mengkaji gaya bahasa yang difokuskan terhadap diksi dan bahasa figuratifnya saja, serta menggunakan komik sebagai alternatif bahan ajar di SMA.

\section{Metode}

Penelitian ini termasuk dalam penilitian deskriptif kualitatif. Bogdan dan Taylor dalam Moleong, 2018: 4) mendefinisikan metodologi kualitatif sebagai prosedur penelitian yang menghasilkan data deskriptif berupa kata-kata tertulis atau lisan dari orang-orang dan perilaku yang dapat diamati. Subjek dari penelitian ini adalah Komik Si Juki: Lika-Liku Anak Kos karya Faza Meonk, sedangkan objek penelitian ini adalah analisis diksi dan bahasa figuratif pada komik $\mathrm{Si}$ Juki: Lika-Liku Anak Kos karya Faza Meonk sebagai alternatif bahan ajar di SMA. Metode dan teknik pengumpulan data yang digunakan untuk mendapatkan data dalam penelitian ini adalah dengan metode kualitatif dan teknik yang digunakan yaitu teknik baca catat dengan studi 
kepustakaan. Studi kepustakaan disebut juga teknik pengumpulan data dengan melakukan penelaahan terhadap buku, literatur, catatan, serta berbagai laporan yang berkaitan dengan masalah yang ingin dipecahkan. Dalam penelitian ini instrumennya adalah orang atau human instrument, yaitu peneliti itu sendiri sebagai peneliti dengan pengetahuannya menjaring data. Alat yang digunakan untuk membantu peneliti adalah kartu data. Jenis teknik analisis data yang digunakan dalam penelitian ini adalah teknis analisis data non statistik yang berisi deskripsi kualitatif. Teknis analisis karya yang merupakan suatu teknik penyelidikan dengan mengadakan penelitian atau penganalisisan terhadap hasil karya.

\section{Hasil dan Pembahasan}

Hasil penelitian ini akan membahas tiga hal, yaitu (1) diksi yang terdapat pada komik "Si Juki: Lika-Liku Anak Kos" oleh Faza Meonk, (2) bahasa figuratif yang terdapat dalam komik Si Juki Lika-Liku Anak Kos karya Faza Meonk, dan (3) kesesuaian komik Si Juki: Lika-Liku Anak Kos karya Faza Meonk sebagai alternatif bahan ajar di SMA.

\section{Diksi dalam Komik Si Juki: Lika-Liku Anak Kos Karya Faza Meonk}

Berdasarkan analisis yang sudah dilakukan, terdapat berbagai aspek diksi pada komik "Si Juki: Lika-Liku Anak Kos." Aspek diksi yang terkandung dalam komik Si Juki: Lika-Liku Anak Kos karya Faza Meonk, meliputi (1) kata konotatif sebanyak 2 kata, (2) kata konkret sebanyak 15 kata, (3) kata asing sebanyak 26 kata, (4) kata sapaan khas dan nama diri sebanyak 7 kata, (5) kata vulgar sebanyak 2 kata, (6) kata seru khas Jawa sebanyak 1 kata, dan (7) kata dengan objek realitas alam sebanyak 4 kata.

\section{a. Kata Konotatif dalam Komik SiJuki: Lika-Liku Anak Kos Karya Faza Meonk}

Berikut ini dapat dilihat pembahasan beberapa kutipan kata konotatif yang dimanfaatkan oleh Faza Meonk.

(1) Kos gue udah kayak hutan belantara, lo bisa menemukan banyak hal di sini. (Meonk, 2020: Tema 45)

(2) Namanya juga ada kos-an fakir kuota, ada wifi gratisan di kampus, ya, harus dimaksimalkan. (Meonk, 2020: Tema 48)

Bentuk kata 'hutan belantara' pada data (1) merupakan kata konotatif yang menggambarkan suasana latar tempat. Di mana tempat kos-an Juki sudah seperti hutan belantara yang artinya hutan yang begitu lebat dengan pohon yang sudah berumur tua. Kata tersebut mengandung makna bahwa kos-an yang ditempati Juki sudah tidak terurus, berantakan bahkan dapat menemukan apa saja di dalam kos tersebut. Dengan penggunaan kata konotatif tersebut pembaca dapat membayangkan suasana yang terjadi di tempat kos-an Juki.

Bentuk kata 'fakir kuota' pada data (2) merupakan kata konotatif yang menggambarkan situasi kejadian dalam cerita. Di mana tokoh Juki merasa kurang memadai di tempat kos-an yang ia tinggali. Kata 'fakir kuota' yang berarti sangat kekurangan kuota menjadi kalimat yang efektif untuk digunakan. Pada kalimat tersebut mengandung makna bahwa kos-an yang ia tempati sangat kekurangan kuota, jadi ketika ada wifi gratis di kampus Juki harus memaksimalkan fasilitas yang ada.

\section{b. Kata Konkret dalam Komik Si Juki: Lika-Liku Anak Kos Karya Faza Meonk}

Berikut contoh pembahasan kutipan kata konkret yang dimanfaatkan oleh Faza Meonk.

(3) “Juk, setrikaan gue mana? Mau gue pake soalnya!” (Meonk, 2020: Tema 8)

Bentuk kata 'setrikaan' pada data (3) merupakan kata konkret karena memiliki makna harfiah, atau menunjukkan pada langsung ke arti wujud bendanya. Penggunaan 
kata konkret tersebut pembaca sudah paham secara langsung apa yang dimaksud. Kata 'setrikaan' pada kalimat tersebut menggambarkan kondisi fisik suatu benda. Di mana pada kutipan tersebut tokoh menanyakan setrikaan pada Juki, karena ia mau memakainya.

c. Kata Asing dalam Komik SiJuki: Lika-Liku Anak Kos Karya Faza Meonk Meonk.

Berikut contoh pembahasan kutipan kata asing yang dimanfaatkan oleh Faza

(19) “Mantep sih Juk, ini lo jadi reseller gitu, atau gimana sih?” (Meonk, 2020: Tema 10)

Bentuk kata 'reseller' pada data (19) merupakan kata asing yang berarti pengecer/ perusahaan yang membeli produk dari pabrik untuk dijual kembali. Pengarang menggunakan kata asing tersebut agar kalimat menjadi lebih efektif dan memberikan efek kesegaran dalam berbahasa. Kutipan kalimat tersebut mengandung makna bahwa tokoh menanyakan pada Juki apakah si Juki yang menjadi reseller atau bukan.

d. Kata Sapaan Khas dan Nama Diri dalam Komik SiJuki: Lika-Liku Anak Kos Karya Faza Meonk

Berikut contoh pembahasan kutipan kata sapaan khas dan nama diri yang dimanfaatkan oleh Faza Meonk.

(45) "Baiklah, berhubung masih ada sisa nasi, chef Juki bakal masakin sesuatu buat lo.." (Meonk, 2020: Tema 11)

Bentuk kata 'chef Juki' pada data (45) merupakan kata nama diri yang diberikan oleh diri sendiri. Nama sapaan tersebut diberikan oleh diri sendiri untuk menunjukkan bahwa dirinya pandai memasak. Sehingga, Juki menamai diri sendiri dengan sebutan chef Juki. Pengarang menggunakan kata sapaan tersebut agar pembaca dapat membayangkan situasi dalam cerita tersebut, di mana tokoh Juki yang pandai memasak dan kretaivitasnya yang dapat membuat masakan apa saja meskipun bahan yang tersedia hanya dari sisan nasi kemarin.

e. Kata Vulgar dalam Komik Si Juki: Lika-Liku Anak Kos Karya Faza Meonk

Kata Vulgar adalah penggunaan kata yang kurang beradab, tidak bijak, dipandang tidak bermoral, dan kurang memiliki sopan santun atau etika sosial yang berlaku dalam masyarakat. Berikut contoh pembahasan kutipan kata vulgar yang dimanfaatkan oleh Faza Meonk.

(51)“Kampret.. Ini lo lagi joget apaan sih?” (Meonk, 2020: Tema 11)

Bentuk kata 'kampret' pada data (51) merupakan kata vulgar karena kata-kata yang digunakan kurang sopan untuk diucapkan. Kata vulgar tersebut diucapkan oleh tokoh Joko untuk menggambarkan rasa kekesalannya terhadap Juki.

f. KataSeru Khas Jawa dalam KomikSiJuki:Lika-LikuAnakKos Karya Faza Meonk Meonk.

Berikut pembahasan kutipan kata seru khas Jawa yang dimanfaatkan oleh Faza

(53) "Tenang mbahmu! Tadi itu gue ketiduran pas lagi sikat gigi! Soalnya dah 3 hari begadang ngerjain tugas!" (Meonk, 2020: Tema 28)

Bentuk kata 'mbahmu' pada data (53) merupakan kata seru khas Jawa. Kata tersebut sudah menjadi bahasa yang sering didengar. Kata tersebut digunakan untuk menunjukkan rasa kekesalan terhadap teman-temannya yang mengira dirinya pingsan dengan melontarkan bahasa khas Jawa, yaitu 'mbahmu'.

g. Kata dengan Objek Realitas Alam dalam Komik Si Juki: Lika-Liku Anak Kos Karya Faza Meonk 
Kata dengan Objek Realitas Alam adalah kata yang memanfaatkan realitas alam sebagai bentukan kata tertentu yang memiliki arti (Al-Ma'aruf. 2009: 57). Berikut contoh kutipan kata dengan objek realitas alam yang dimanfaatkan oleh pengarang.

(55) Di pagi yang cukup cerah.. Waktu yang tepat untuk ibu kos mengupdate gosip di lingkungan warga. (Meonk, 2020: Tema 17)

Bentuk kata 'pagi yang cerah' menurut data (55) merupakan kata dengan objek realitas alam. Kata tersebut menunjukkan suasana pagi hari yang begitu cerah. Di mana warga khususnya ibu-ibu bergosip. Pembaca dapat menggambarkan dengan jelas suasana di pagi hari itu.

\section{Bahasa Figuratif dalam Komik SiJuki Lika-Liku AnakKos Karya Faza Meonk}

Berdasarkan analisis yang sudah dilakukan, terdapat berbagai aspek bahasa figuratif dalam komik Si Juki: Lika-Liku Anak Kos karya Faza Meonk. Aspek bahasa figuratif yang terkandung dalam komik Si Juki: Lika-Liku Anak Kos karya Faza Meonk, meliputi (1) majas, (2) idiom, dan (3) peribahasa.

a. Majas dalam Komik SiJuki: Lika-Liku Anak Kos Karya Faza Meonk

Aspek majas yang terkandung pada komik "Si Juki: Lika-Liku Anak Kos" karya Faza Meonk, meliputi metafora, simile, dan personifikasi.

\section{a) Majas Metafora dalam KomikSiJuki:Lika-LikuAnakKosKarya Faza Meonk}

Metafora yaitu majas seperti simile, bedanya metafora tidak menggunakan katakata pembanding seperti bagai, laksana, sebagai, seperti, dan sebagainya. Metafora itu melihat sesuatu dengan perantaraan benda yang lain (Becker dalam Pradpo (2000:61-78). Berikut pembahasan kutipan majas metafora yang dimanfaatkan oleh pengarang. (58)Kos-an adalah kawah candradimuka bagi kami. (Meonk, 2020: Tema 50)

Bentuk kalimat pada data (58) tersebut merupakan majas metafora karena menerangkan suatu keadaan yang sama dengan hal yang lain, di mana sesungguhnya hal tersebut tidaklah sama. Pada kalimat tersebut terlihat dengan jelas bahwa Juki menyamakan tempat kos-annya sama dengan kawah candradimuka.

\section{b) Majas Simile dalam KomikSiJuki: Lika-LikuAnakKos Karya Faza Meonk}

Simile yaitu majas yang menyamakan satu hal dengan hal lain dengan menggunakan kata-kata pembanding seperti: bagai, sebagai, semisal, seperti, seumpama, ibarat, dan lainlain. Berikut pembahasan beberapa kutipan majas simile yang dimanfaatkan oleh Faza Meonk.

(59) Kos-an adalah kawah candradimuka bagi kami. Sebagaimana gatot kaca, kos-an membuat kami lebih kuat dan tegar menghadapi segala kesulitan. (Meonk, 2020: Tema 50)

Bentuk kalimat pada data (59) merupakan majas simile karena tokoh Juki membandingkan sesuatu hal dengan hal lainnya. Pada kalimat tersebut terlihat jelas tokoh Juki membandingkan tempat kos-an yang ia tinggali dengan gatot kaca. Di mana gatot kaca yang dikenal sebagai wayang yang kuat, Juki pun membandingkannya dengan dirinya. Juki membandingkan dirinya hidup di kos-an menjadi seperti gatot kaca, karena membuatnya terasa lebih kuat dan tegar menghadapi segala kesulitan.

\section{c) Majas Personifikasi dalam KomikSiJuki: Lika-Liku AnakKos Karya Faza Meonk}

Majas ini menyamakan benda dengan manusia, benda-benda mati dibuat seolaholah dapat berbuat, berpikir, melihat, mendengar, dan sebagainya seperti manusia. Berikut contoh pembahasan kutipan majas personifikasi yang dimanfaatkan oleh Faza Meonk. 
(62)“Duh kasian ini pipanya, nggak pernah disayang-sayang, dielus-elus, dikasih makan..” (Meonk, 2020: Tema 24)

Bentuk kalimat pada data (62) merupakan majas personifikasi karena tokoh mbah gendeng menyamakan benda pipa dengan manusia. Kalimat tersebut terlihat jelas bahwa tokoh mbah gendeng menyamakan benda pipa dengan manusia, di mana benda pipa tersebut diajak berbicara, dielus-elus, seolah-olah benda pipa dapat merasakan dan mendengar seperti manusia.

\section{b. Idiom dalam Komik SiJuki: Lika-Liku Anak Kos Karya Faza Meonk}

Idiom merupakan bahasa figuratif yang mempunyai Majas ini menyamakan benda dengan manusia, benda-benda mati dibuat seolah-olah dapat berbuat, berpikir, melihat, mendengar, dan sebagainya seperti manusia. kekhasan bentuk dan makna di dalam kebahasaan yang tidak dapat diterjemahkan secara harfiah. Berikut contoh pembahasan kutipan idiom yang dimanfaatkan oleh Faza Meonk.

(66) “Aduh! Pantesan ini dompet ringan.. Udah kosong!” (Meonk, 2020: Tema 6)

Bentuk kalimat pada data (66) merupakan idiom karena memiliki makna khas yang tidak dapat diterjemahkan secara harfiah. Kata 'dompet kering' mengandung makna dompet kosong, sedang kekurangan uang. Kalimat tersebut menjelaskan bahwa tokoh Juki sudah kehabisan uang, dompetnya kosong.

\section{c. Peribahasa dalam Komik Si Juki: Lika-Liku AnakKos Karya Faza Meonk} Meonk.

Berikut contoh pembahasan kutipan peribahasa yang dimanfaatkan oleh Faza

(69) Lampu menyala, namun redup. Seolah hidup tak mau mati pun tak sanggup. (Meonk, 2020: Tema 26)

Bentuk kalimat pada data (69) tersebut mengandung peribahasa perumpamaan karena membandingkan suatu keadaan. Kalimat tersebut menjelaskan suatu keadaan ketika lampu yang menyala, namun redup. Di situlah diumpamakan seperti ingin hidup tapi tidak mampu, sedangkan untuk mati pun tidak sanggup.

\section{Kesesuaian Komik Si Juki: Lika-Liku Anak Kos Karya Faza Meonk Sebagai Alternatif Bahan} Ajar di SMA

Komik Si Juki: Lika-Liku Anak Kos dalam penelitian akan dianalisis kesesuaiannya sebagai alternatif bahan ajar di SMA berdasarkan pada 3 (tiga) aspek kriteria bahan ajar yang telah dikemukakan oleh Rahmanto, selain itu akan disesuaikan pula berdasarkan Kurikulum 2013 revisi 2018. Uji kesesuaian terhadap komik tersebut sebagai berikut.

\section{a. Kesesuaian Komik Si Juki: Lika-Liku Anak Kos Karya Faza Meonk sebagai} Alternatif Bahan Ajar Sastra di SMA Berdasarkan Teori

Kriteria bahan ajar menurut Rahmanto terdapat 3 aspek, meliputi (1) aspek bahasa, (2) aspek psikologis, dan (3) aspek latar belakang budaya. Berdasarkan analisis yang telah dilakukan, komik Si Juki: Lika-Liku Anak Kos Karya Faza Meonk sesuai dengan kriteria bahan ajar yang dikemukakan oleh Rahmanto. Jadi dapat disimpulkan bahwa komik dapat dijadikan sebagai alternatif bahan ajar di SMA. Karena, dilihat dari segi bahasa, gaya bahasa yang digunakan dalam komik tersebut sangat mudah dipahami oleh pembaca, menggunakan bahasa sehari-hari, namun masih memiliki makna tertentu, serta menarik.

Dilihat dari segi psikologis komik tersebut memuat berbagai situasi, memiliki kreativitas yang bagus, mampu memecahkan masalah, serta saling bekerja sama, sehingga secara tidak langsung dapat membantu perkembangan psikologis pembaca atau peserta didik. Kemudian dari segi latar belakang budaya, pada cerita komik tersebut memuat memuat nila moral yang dapat dijadikan sebagai contoh dalam kehidupan, sehingga peserta didik dapat mengambil berbagai pelajaran yang positif melalui komik tersebut. b. Kesesuaian Komik Si Juki: Lika-Liku Anak Kos Karya Faza Meonk sebagai 


\section{Alternatif Bahan Ajar di SMA dengan Konsep Kurikulum 2013 Revisi 2018}

Kompetensi dasar yang digunakan dalam penelitian ini adalah 3.8 dan 4.8. Pada Kompetensi Dasar 3.8 siswa diminta untuk mengidentifikasi nilai nilai kehidupan yang terkandung dalam kumpulan cerita pendek yang dibaca. Pada Kompetensi Dasar 4.8 siswa diminta untuk mendemonstrasikan salah satu nilai kehidupan yang dipelajari dalam cerita pendek. Penelitian ini sesuai dengan kompetensi dasar tersebut karena antara komik dengan cerpen sama-sama berisi tentang cerita pendek, hanya saja komik terdapat gambar di dalam ceritanya, sedangkan cerpen tidak.

\begin{tabular}{cll}
\hline No. & $\begin{array}{l}\text { Kurikulum } \\
\mathbf{2 0 1 3} \\
\text { Revisi 2018 }\end{array}$ & \multicolumn{1}{c}{ Keterangan } \\
\hline 1. & Kompetensi inti 1-4 & $\begin{array}{l}\text { Berdasarkan kompetensi inti 1-4 tersebut, } \\
\text { komik "Si Juki: Lika-Liku Anak Kos" karya } \\
\text { Faza Meonk dapat dijadikan sebagai } \\
\text { alternatif bahan ajar di SMA. }\end{array}$ \\
& Kompetensi Dasar & $\begin{array}{l}\text { Berdasarkan kompetensi dasar 3.9 dan 4.9 } \\
\text { tersebut, komik "Si Juki: Lika-Liku Anak } \\
\text { Kos" karya Faza Meonk dapat dijadikan } \\
\text { sebagai alternatif bahan ajar di SMA. }\end{array}$ \\
\hline
\end{tabular}

Peneliti memilih komik sebagai bahan ajar agar dapat lebih menarik para peserta didik. Selain itu, komik tersebut dapat digunakan sebagai alternatif bahan ajar sastra dengan materi pembelajaran menemukan unsur intrinsik dan ekstrinsik cerpen serta unsur kebahasaan dalam cerpen. Oleh sebab itu, komik Si Juki: Lika-Liku Anak Kos sesuai dengan Kurikulum 2013 Revisi 2018 Kompetensi Inti 1-4 Kompetensi Dasar 3.8 dan 4.8.

\section{Simpulan}

Berdasarkan hasil penelitian tersebut, diksi dan bahasa figuratif pada komik "Si Juki: LikaLiku Anak Kos" karya Faza Meonk sebagai alternatif bahan ajar sastra di SMA, dapat disimpulan bahwa, dari hasil analisis yang telah diuraikan sebelumnya mengenai komik tersebut, diksi menjadi aspek gaya bahasa yang paling banyak digunakan oleh Faza Meonk sejumlah 57 kata. Diksi yang terdapat dalam komik tersebut, meliputi kata konotatif, kata konkret, kata asing, kata sapaan khas dan nama diri, kata vulgar, kata seru khas Jawa sebanyak, dan kata dengan objek realitas alam. Penggunaan diksi yang paling sering digunakan dalam komik adalah kata-kata asing, yaitu sebanyak 26 kata. Pemanfaatan kata asing dipilih oleh pengarang untuk memberikan efek makna yang lebih berkesan. Selain itu, dapat menggambarkan karakter tokoh dengan jelas. Penggunaan kata asing dipilih agar bahasa menjadi lebih kekinian, dapat menambah kosakata para pembaca. Selaras dengan hasil analisis yang dilakukan, tidak ditemuinya kata arkaik pada komik Si Juki. Hal tersebut karena kata arkaik termasuk kata yang sudah mati dihidupkan lagi atau dengan kata lain yaitu kata yang digunakan pada masa lampau. Sedangkan dalam komik Si Juki 
gaya bahasa yang digunakan cenderung memakai bahasa yang modern sesuai dengan perkembangan. Aspek bahasa figuratif yang terdapat dalam komik terseebut, meliputi (1) majas, (2) idiom, dan (3) peribahasa. Penggunaan bahasa figuratif yang paling sering dimanfaatkan oleh pengarang yaitu majas sebanyak 8 kali. Pemanfaatan bahasa majas dipilih oleh pengarang untuk memberikan efek indah dalam bahasa, memberikan kesegaran dalam berbahasa. Dengan menggunakan majas pembaca dapat menggambarkan suasana yang terjadi secara konkret.

Dari tiga aspek kriteria bahan ajar yang disampaikan oleh Rahmanto, yaitu aspek bahasa, aspek psikologi, dan aspek latar belakang budaya serta Kurikulum 2013 Revisi 2018 KI 1-4 KD 3.8 dan KD 4.8, maka dapat disimpulkan bahwa komik "Si Juki: Lika-Liku Anak Kos" karya Faza Meonk menjadi alternatif yang tepat untuk dijadikan sebagai bahan ajar sastra di SMA karena memenuhi semua kriteria tersebut. Hal tersebut dapat dilihat dari kesesuaian aspek kriteria bahan ajar yang telah dijabarkan di pembahasan.

\section{DAFTAR PUSTAKA}

[1] Al-Ma'ruf, A. I. (2009). Stilistika Teori, Metode, dan Aplikasi Pengkajian Estetika Bahasa. Solo: Cakrabooks Solo.

[2] Batubara, A. F. (2013). Pemanfaatan Media Komik Untuk Meningkatkan Kemampuan Menulis Cerpen Siswa Kelas X SMA Negeri 2 KABANJAHE.

[3] Febriani, A. F., Rakhmawati, A., \& Anindyarini, A. (2019). Diksi dan Gaya Bahasa Pada Cerpen "Anak Ini Mau Mengencingi Jakarta?" dan Relevansinya Dengan Materi Ajar Di SMA. BASASTRA Jurnal Bahasa, Sastra, Dan Pengajarannya, 126(1), 1-7.

[4] Kurniawan, A. (2017). Gaya Bahasa dalam Meme Indonesia: Kajian Stilistika Sastra (Issue 13). Skripsi. Universitas Diponegoro: Semarang.

[5] Meonk, F. (2020). Si Juki Lika-Liku Anak Kos. Jakarta: PT. Gramedia.

[6] Moleong, L. J. (2018). Metode Penelitian Kualitatif. Bandung: PT. Remaja Rosdakarya. Rahmanto, B. (1988). Metode Pengajaran Sastra. Yogyakarta: Kanisius (Anggota IKAPI).

[7] Wellek, R., \& Warren, A. (2016). Teori Kesusastraan. Jakarta: PT. Gramedia. 